International Reserves versus External Debts:

Can International reserves avoid future Financial

Crisis in indebted Countries?

Layal Mansour

September 2013 


\section{GATE Groupe d'Analyse et de Théorie Économique Lyon-St Étienne}

93, chemin des Mouilles 69130 Ecully - France

Tel. +33(0)4 72866060

Fax $+33(0) 472866090$

6, rue Basse des Rives 42023 Saint-Etienne cedex 02 - France

Tel. +33 (0)4 77421960

Fax. +33 (0)4 77421950

Messagerie électronique / Email : gate@gate.cnrs.fr

Téléchargement / Download : http://www.gate.cnrs.fr - Publications / Working Papers 


\title{
International Reserves versus External Debts: \\ Can International reserves avoid future Financial Crisis in indebted \\ Countries?
}

\author{
Layal MANSOUR, Ph.D Candidate \\ Université de Lyon, Lyon, F-69007, France; CNRS, GATE Lyon Saint-Etienne, Ecully, F- \\ 69130, France; Université Lyon 2, Lyon, F-69007, France.
}

mansour@gate.cnrs.fr

\begin{abstract}
The aim of this paper is to evaluate the economic consequences on the countries that on one hand protect themselves from future financial crises by accumulating international reserves (IR) while on the other hand expose themselves to severe financial crisis due to their excessive internal and/or external public debt. Using the Financial Stress Indicator (FSI) proposed by Balakrishnan et al (2009) and IMF -which cover several aspects of financial crisis- and by applying the Markov switching model with time varying, we estimated the probability whether an indebted country is vulnerable to crises despite its accumulation of IR -acting as a buffer stock and self-insurance-. We studied the case of five emerging countries in Asia and Latin America that had increased both of their IR and public debts, and found that debt had increased the likelihood for a country to suffer from financial crisis, however IR did not necessarily provide "Peace" in the indebted countries except of some exceptions. We conclude that although debt and international reserves have theoretically opposite economic concerns for a country, the deleterious effects of debts might outweigh in most cases the beneficial effects of IR
\end{abstract}

Keywords: Monetary policy, International Reserves, External Debts, Financial Crisis, Financial Stress Indicator.

Mots clefs : Politique Monétaire, Réserves Internationale, Dettes Externes, Crise Financière, Indice de stress financier.

JEL: C22, E52, F31, G01, H63, 


\section{I-Introduction}

The aim of this paper is to evaluate the economic consequences of countries, which at the same time are exposing themselves to risks of triggering financial crises by increasing their internal debts (ID) and / or external debts (ED), but also protect themselves from future financial crises by accumulating International Reserves (IR). Using the financial stress indicator (FSI), which estimates the likelihood of a country to be victim of a financial crisis given its domestic economy, we will determine which of IR or debts affect more the crisis. The majority of previous studies were designed to determine whether or not there is a positive / negative relationship between an aggregate / feature economic and financial crisis such as the positive relationship between financial openness and crises through financial intermediaries (Caballero and Krishnamurthy 2001, Prassad et al 2004, Mishkin 2005, Rancière 2006, Dufrénot et al, 2011), and positive relationships between exchange rates and crises (Kaminsky et al 1998, Reinhart 2000, Obstfeld 2004, ), and between debt and crises (Rajan et al 2009, Benmelech et al 2011) and between regulation and crisis (Aizenman 2009, Mishkin 2011) and finally between Foreign Direct Investment and Debt Crisis (Reinhart and Rogoff 2008a). In this present paper, we aim to analyze two variables that have opposite effect on the financial crises. We will base our paper on the hypothetical conclusions of previous studies:

1 - International reserves, as explained by Aizenman and Marion (2004), Calvo (2006), Aizenman and Lee $(2007,2008)$ and Aizenman et al (2010), are considered such as buffer stock, hence the role of "self-insurance" against financial crises caused primarily by external drain. Indeed, the 90s-2000s were marked by severe financial crises, mainly involving more countries in Latin America and East Asia who are "dependent" from foreign currency and economic results of their faults (excess debts, trade deficits and / or their rate of de-facto dollarization). Since these dramatic events, countries proved a "psychological impact" as defined by Aizenman et al (2010) and seek to hedge against any recurrence. Since then, the accumulation of foreign reserves is growing up feeling the "fear of losing International reserves" in order to guarantee stability in the exchange rate following the intervention of systematic markets as it was mentioned by Calvo and Reinhart (2002). 
2- In addition to its "auto-insurance" effect against crises, hoarding International reserves can promote a mercantilist export promotion, especially in the exporting countries or emerging countries. In other way, the purchase of foreign currencies encourages the depreciation of the domestic currency or at least keeps the exchange rate of the national currency stable, thus resulting in better external competitiveness and promoting export. Finally, hoarding International reserves can be a tool of richness for a country by providing equilibrium and economic growth to the economy (Vidon, 2007).

3 - Debts and more precisely external debt in foreign currency are for the most cases, the major cause for triggering the crisis and practically the main cause of the Asian crisis and Latin America especially for countries that adopt a more or less flexible exchange rate (Calvo and Mishkin ,2003), hence recent crisis (end of 1990 and begin of 2000) were define as “foreign debt crisis years". According to Reinhart and Rogoff (2008 and 2009), domestic debt as well as external debt is very dangerous for the economy, and an increase of about $90 \%$ and $60 \%$ respectively of domestic debt and external debt can be an alert for a future financial crisis. Moreover, consequences in the economy growth of external debt are even more than two times more dangerous than domestic debt. Reinhart, 2010 mentioned that no country is totally protected from by a financial crisis.

Emerging countries that accumulate foreign reserves, almost sterilize them. The sterilization according to Calvo in 1991 increases the internal debts after they monetize. However, the domestic debts are as dangerous as external debts (Calvo, 2006), and represent the key barrier to Economic Progress and sources of Macroeconomics vulnerability.

From these above assumptions, we go on with this article to answer the following question: Given that the accumulation of foreign reserves acts as a "moderator shock" or "selfinsurance" against potential financial crises, and given that debts (domestic and / or foreign) are the causes that weaken economies and expose them to eventual financial crisis, what would be the consequences of a country characterized by both increasing debts (increased risk) and accumulation of international reserves (reduced risk)? In other words, will an indebted country and "secured" by hoarding IR be safe from crises? 
To answer these questions, we will therefore only focus on debt (internal and / or external), vis-à-vis the accumulation of international reserves, despite the presence of other economic factors (exchange rates, interest rates, financial openness, economic policy, inflation ...) that can have positive relation with financial crisis.

The countries that will be studied ${ }^{1}$ are Turkey, Russia, Mexico, Argentina and Brazil. Other countries like Korea and Lebanon would be of interest to include in our study because of their very high level of hording international reserve, and their important level of debt (Domestic debt for Japan and external and domestic debt for Lebanon) but due incomplete data, these countries will be studied later, in further article.

The financial crisis and its probability will be measured using the TVTPMS model to study the "offset" of the indicator of financial stress FSI when we add external variables such debt and IR. The FSI includes five different financial aspects, all interconnected. 1-The pressuremarket exchange rate, 2-the default risk, 3-the beta of banking, 4- the stock price return and 5time varying stock return volatility. Details will be treated below.

This model does not predefine the date of onset of the crisis or the date of the crisis, but determine the main endogenous variables responsible to secure or undermine the financial market of each country. In other words, this model gives us the probability whether a country will or will not have a crisis, by analyzing its endogenous economic characteristics.

In the second part of this paper, we will quote the literature on the risks of debt and the benefits of reserve accumulation. Then the third part will focus on the theoretical model and the details of the data. Finally the fourth part concerns the interpretation of results. Conclusion will end the study with quick summary of results and of contribution to economic.

${ }^{1}$ Lebanon and Japan will be continued in further studies 


\section{II-Literature}

\section{A- From Debt and Financial Integration to Financial Crisis}

Even though most recent financial crises originate from the United States, emerging countries have suffered too: as a result of strong financial and economic integration.

With the world globalization, financial openness is now inevitable. Its advantages especially in emerging countries are studies by Hoxha et al, (2009), Obsfeld (2009), Kose et al (2008), Prasad et al (2004), Mishkin (2005), Ranciere, et al (2006), Reinhrad and Tokatlidis (2002) and many other economist who concluded that financial openness can promote welfare growth (Hoxha et al 2009), expansion of financial sector, growth of GDP (Bekaert, Harvey and Lundbld 2005), increase inflows when financial openness is associated with a decrease in price and relax the constraints borrowing.

Therefore, we can witness how Brazil, Argentina, Mexico, Turkey, Russia, and other countries have opened their financial market in order to increase their financial liberalization. However the positive effect of the financial openness is not automatic, and may even be not apparent, but in contrary, as criticized by Kaminsky and Smuckler (2002), Ben Grama and Clévenot (2007), Bénassy-Quéré (2005), Williamson et Mahar (1998), Ranciere, et al (2006), Obsfeld (2009), financial integration weaken the internal financial system, increase risk, and therefore, increase probability to get a financial crises, thus a recession; especially when the internal economy of a country is not compatible with the financial integration, in other words, when the Mundell trilemma is not respected. To illustrate several crises in Mexico in 1994, Korea in 1997, Brazil in 1998, Argentina and Turkey in 2000 were due to their fix exchange rate regime, which was not compatible with the financial integration. As for Israel for example, who does not have a fix exchange rate, has avoided such a crisis.

However, financial liberalization is not the unique responsible nor the main reason of those crisis. According to Calvo (2006), "Nothing is more disastrous" than to open the financial market while being financially crippled by a high debt. Latin America emerging countries that have dollarized debts (which should repay their debts in foreign currencies), and therefore are dependent on the exchange rate (if floating regime) become economically weak and susceptible to potential financial crises (Calvo, 2006). 
Indeed, Calvo and Mishkin (2003) explained how the foreign debts have been the result of worsened the crisis of Asian countries and Argentina, especially for flexible (managed) exchange regime like the one adopted previously in Turkey. In fact, Eishengreen and Hausmann (1999) explained how it is risky for a country that is no more capable to borrow abroad in its local currency; they called such situation of dollarized debt as "Original Sin."

\section{B-From Financial Crisis to hoarding International Reserves}

Hoarding of international reserves (IR) is often conceived as exclusive to the Emerging Market Countries (EMC). They share around 65\% of global reserves in 2008. In 2010, six Asian countries were among the world's largest holder of IR. This increasing trend became remarkable in the post-crisis era in Eastern Asia and Latin America. The basic source of the IR growth is the persistent current account surplus. As mentioned earlier, the first main reason for the course of hoarding IR, as described by economists listed above ${ }^{2}$, is that it offers a precautionary self-insurance against financial crisis. In fact, those countries have suffered from sudden stop crisis that caused a psychological impact in the region, and so made EMC look for a build up ample war chest of IR to protect themselves eventually against a new same type of crisis. The second main reason of hoarding IR is that IR occur a mercantilist export promotion. This means that buying foreign currencies permit to hold down domestic currencies and therefore improve external competitiveness and promote exports. In addition to the exchange rate stability after systematic foreign market interventions that can offer the growth of IR (Calvo and Reinhart 2002)

Finally, IR can be considered for a country such a degree of solvability, and the loss of IR may indicate deterioration in the credit worthiness of the country.

Briefly, many authors proved that IR can avoid financial crisis, when the financial integration is not well managed. But can IR avoid debt crisis?

Let us consider for example, countries such Korea, Chili, Argentina and other that suffered from "flight to quality" of their inflow, which consist of capital flight of investors in order to invest in other countries more securely. Their IR permit to confront exchange crisis for a while and to avoid the bankruptcy of the banking system, especially when IR covered external debt, as in Korea.

\footnotetext{
2 Aizenman and Marion (2004), Calvo (2006), Aizenman et Lee (2007, 2008) and Aizenman et al (2010), Ben-Brassat et Gottlied(1992), Rodrik et Velasco (1999); Cheung et Ito (2007) et Obsfeld et al (2008).
} 
The relation between debt and IR is treated by several authors. Increase the IR and external debt have a positive relation according to Dominguez (2009), and Obsfeld et al (2009), and in some cases, if IR are sterilized, external debt will prompt rises in domestic debt by monetizing it (Calvo 1991).

According to Calvo (2003), a country that has an excessive external debt, hoarding reserves will not be sufficient to avoid a crisis, but may be useful during the "sudden stop" crises (2006). As mentioned by the "Grennspan-Guidotti" rule, an adequate level of IR should exceed the level of short-term external debt. This rule has for years been considered as the most adherents and empirical support. Recently, Obsfeld et al (2009) mentioned that despite the focus on the "Guidotti- Greenspan" rule and sudden stops in the literature, short term external debt is not a significant predictor of reserve holdings, though another variable often considered in more traditional models, the Trade to GDP ratio is.

\section{III- Empirical Framework}

\section{A-The measurement of the Financial Stress Indicator}

The literature is almost based on narrative evidence (expert judgment), to determine different types of crisis, with the need of some selected indicators that point to historical regularities such the exchange rate devaluation and the state of foreign reserve (e.g. Eichengreen and Bordo, 2002; Kaminsky and Reinhart, 1999; Reinhart and Rogoff,2009; Laeven and Valencia,2008). These latter narratives were essential in order to complete the empirical studies of Goldstein et al, 2000, and constructing/using binary variables

The empirical studies (e.g Goldstein et al., 2000) used binary variables that were constructed based on these narratives. Binary crisis variables don't consider periods of small scale stress that did not result in full-blown crisis. This latter is considered by the continuous stress indicator, which is its main advantage.

The Financial Stress Index was defined differently from a financial institution to another, for example, Starting with the Bank Credit Analyst (BCA), the financial stress index for the USA was reported monthly, based on the performance of banking shares as compared to whole stock market, credit spreads and the slope of the yield curve, and the new issues of stock, bonds and consumer confidence. 
As for the JP Morgan, the index measures the Liquidity, Credit Volatility Index LCVI is based on seven variables: 1-The US Treasury curve error (standard deviation of the spread between on-the-run and off-the-run US Treasury bills and bonds along the entire maturity curve),2- the 10 years US swap spread, 3-US high-yield spreads, 4-JP Morgan's Emerging Market Bonds index, 5- foreign exchange volatility (weighted average of 12-month implied volatilities of several currencies), 6-the Chicago board of exchange equity index VIX, and 7the JP Morgan Global Risk Appetite Index.

In Canada, The FSI was based on equity, bond, foreign exchange markets and the banking sector. The index used was developed by Illing and Liu (2006) using a standard measure and refined measure of each stress component, where the former refers to the variables and their transformations that are commonly found in the literature, while the latter incorporates the adjustments that allow for better extraction of the information about stressful periods. They explore different weighting schemes to aggregate the individual series ${ }^{3}$ and they perform an expert survey to identify periods that were perceived as especially stressful, confirming that the FSI matches these episodes very well.

The Fed Board of Governors adopted the framework of Carlson et al (2008), similar to the option pricing model (Merton, 1979) that consists to provide a distance-to-default of the financial system, called the Index of financial health ${ }^{4}$. The apply measure to 25 of the largest US financial institutions, confirming its impact on capital investment in the US economy.

Every month the FED of Kansas City published the Kansas Financial Stress which takes into consideration eleven variables (Hakkio and Keeton, 2009) . seven spread between different bond classes by issuers, risk profiles and maturities, correlations between returns on stocks and Treasury bonds, expected volatility of overall stock prices, volatility of bank prices and a cross-section dispersion of bank returns) that are aggregated by principal component analysis.

According to the IMF, the Financial Stress Indicator FSI is defined as a period when the financial system of a country is under strand and its ability to intermediate impaired.

Based on the study of Cardarelli et al (2009), they calculated the index based on highfrequency data, where the price changes are measured with respect to its previous levels or

\footnotetext{
${ }^{3}$ factor analysis, size of a corresponding market on total credit in economy, variance-equal weighting

${ }^{4}$ The method uses the difference between the market value of a firm's assets and liabilities and the volatility of the asset's value in order to measure the proximity of a firm's assets being exceeding by its liabilities
} 
trend value. These variables are standardized and aggregated into a single index FSI usingequal weighting for each country and period.

At the beginning, the FSI comprises three financial market segments (subcomponents): 1banking sector (the slope of the yield curve, TED spread, the beta of banking sector stock), 2securities markets (corporate bonds spread, stock markets returns and time-varying volatility of stock returns), and 3-exchange markets (time varying volatility of NEER changes). Then, Balaskrishnan et al (2009) modify the previous index to account for specific conditions of emerging economies by adding on one hand, the measure of exchange rate pressure (currency depreciation and decline in foreign reserves) and the sovereign debt spread, and on the other hand, the downplaying the banking sector measure (slope of the yield curve and TED spread). Thus, The EM-FSI ${ }^{5}$ used as endogenous variable comprises five variables:1-the "bankingsector beta," denoted as $\beta, 2$-the stock market returns, 3-the time-varying stock market return volatility, 4-the sovereign debt spreads, and 5- the exchange market pressure index (EMPI). The overall index is a composite measure of these sub- indices and captures price changes in these markets relative to past trends as they are likely to signal strain in financial markets or intermediation:

$\boldsymbol{E M - F S I}=\beta+$ Stock market returns + Stock market volatility + Sovereign debt spreads + EMPI

Each variable is demeaned (using the arithmetic mean) and divided by its standard deviation, that is, each variable is standardized.

-A value of zero implies neutral financial market conditions on average across the subindices; while positive values imply financial strain (i.e. prices are on average above means or trends).

-A value of 1 indicates a one-standard deviation from average conditions across sub-indices.

-A value of 1.5 or higher has in the past been associated with a crisis.

The FSI is robust to other weighting schemes, including those based on principal components.

\footnotetext{
${ }^{5}$ The IMF Financial Stress Index has been applied by Melvin and Taylor (2009) to analyze the exchange rate crisis.
} 


\section{Banking Sector:}

The "banking-sector beta" is the standard capital asset pricing model (CAPM) beta, and is defined as follows:

$$
\beta_{i, t}=\frac{\operatorname{COV}\left(r_{i, t}^{M}, r_{i, t}^{B}\right)}{\sigma_{i, M}^{2}}
$$

Where $r$ represents the year-over-year banking or market returns, computed over a 12-month rolling window. In line with CAPM, a beta greater than 1 -indicating that banking stocks move more than proportionately with the overall stock market—-suggests that the banking sector is relatively risky, and would be associated with a higher likelihood of a banking crisis. To better capture banking-related financial stress, the banking beta was recorded only when banking returns were lower than overall market return. Sources: DataStream.

\section{Securities Markets:}

a) Stock market returns are computed as the year-on-year change in the stock index multiplied by minus one, so that a decline in equity prices corresponds to increased securitiesmarket-related stress. Source: DataStream.

b) Stock market volatility is measured as the 6-month (backward looking) moving average of the squared month-on-month growth rate. This volatility measure replaces the previously used GARCH $(1,1)$ specification. The new volatility measure is highly correlated with the old measure (average correlation coefficient of 0.85 ). The change in method was implemented to simplify the construction of the index and to enhance reconstruction of the index. Source: DataStream.

c) Sovereign debt spreads is defined as the bond yield minus the 10-year United States Treasury yield using JPMorgan EMBI Global spreads. When EMBI data were not available, five-year credit default swap spreads were used. Sources: JPMorgan EMBI Global spreads and DataStream

\section{Foreign Exchange Markets}

The EMPI captures exchange rate depreciations and declines in international reserves, and is defined for country $i$ in month $t$ as:

$$
E M P I_{i, t}=\frac{\left(\Delta e_{i, t}-\mu_{i, \Delta e}\right)}{\sigma_{i, \Delta e}}-\frac{\left(\Delta R E S_{i, t}-\mu_{i, \Delta R E S}\right)}{\sigma_{i, \Delta R E S}}
$$


Where $\triangle \mathrm{e}$ and $\triangle R E S$ denote the month-over-month percent changes in the exchange rate and total reserves minus gold, respectively. The exchange rate is taken vis-à-vis an anchor country, as discussed in Levy-Yeyati and Sturzenegger (2005). The symbols $\mu$ and $\sigma$ denote the mean and the standard deviation, respectively, of the relevant series. The index accommodates episodes of hyperinflation, defined as annual inflation rates exceeding 150 percent, by adjusting means and standard deviations for periods with and without the prevalence of hyperinflation. Sources: International Financial Statistics.

All components are available in monthly frequency. The EM-FSI is constructed for 26 countries spanning the period January 1997 to latest available.

Further details and a discussion on the motivation and performance of the aggregate index in signaling past financial crisis can be found in R. Balakrishnan, S. Danninger, S. Elekdag, and I. Tytell (2009) ${ }^{6}$.

As for exogenous variables, we use the International reserves and external debt because of the opposite consequences but with same trend: Obsfeld et al 2008, Dominguez 2007; this means that the more is high the external debt, the more the country will need to accumulate international reserve, and vice versa. We will consider the internal debt by studying the total debt because according to Calvo (2006), domestic debt is as serious and dangerous as external debts. This latter represent the key barriers to economic progress and sources of macroeconomic vulnerability.

\section{Exogenous variables are expressed in the fallowing way:}

1-STED/GDP is (Short Term External Debt on GDP in billion of US dollar and percentage). 2- TED/GDP (Total External Debt on GDP in Billion of US dollar in Billion US Dollar and percentage)

3- STED/TED (Short Term External Debt on Total External Debt in Billion of US Dollar and percentange)

4- STED/IR (“Grennspan-Guidotti” rule)

5-IR/TED (International reserves on Total External Debt in billion of US dollar and percentage)

6- IR/GDP (International Reserve on GDP in Billion of US dollar and percentage)

\footnotetext{
${ }^{6}$ : “The Transmission of Financial Stress from Advanced to Emerging Economies" IMF Working Paper available at http://www.imf.org/external/pubind.htm
} 
Source of all data are from the International Financial Statistics IFS-IMF. Given available data, data is expressed quarterly from Q1 1997 to Q4 2009,

\section{B-The Markov switching Model with Time-varying transition probabilities}

After several crisis such debt crisis, auction crisis and interest rate crisis in 1987, the American recession in 1991, the net bubble in 2000, and the subprime crisis in 2008, economist continuously try to prevent future crisis in order to avoid them and this becomes nowadays the mail objectives of all economists as well as politicians and monetary authorities.

Thus, looking for a statistical definition of a financial crisis, many linear models were introduced in order to analyze financial series. But, the past showed that some crisis have dramatic impact in financial temporal series (Jeanne and Masson 2000, Hamilton 2005), and that financial variables in the financial market have different behaviors.

That's why; understanding the behavior of the financial market becomes crucial by trying to take into consideration non linear variables present in temporal series thus: "the state change" or the "regime change". This latter consist of modeling a temporal series and divided it into two different regimes; in other terms, one series can change to another during time.

This is what we call modeling the regime change with hide Markov Chain.

Introduced in 1978 by Lindgren, this "state change model" was developed and used by Hamilton in 1989 in order to describe business cycles. Later, Gray 1996 and Ang and Bakeart 2001 based their economic studies on Markov framework models series of exchange rate and/or to precise date of business cycle with macroeconomic temporal series.

Consider a two-state Markov switching autoregressive model for the index FSI. Every state, called regime, determine the period of low financial stress, and high financial stress. Although there is studies using model with several regimes (Calvet and Fisher 2004), this article will be limited to a model with two regimes in order to have enough number of "degree de liberté as well as to limit eventual numerical problems during the estimation.

The regimes are not preselected as would be the case if we were using the dummy variable $0 / 1$. Indeed, the model verify whether at a given time $t$, the FSI index is considered to change in a low financial stress or high financial stress regime, owing to the fact that likelihood of being in either regime is governed by a latent unobservable two-state Markov chain variable. 
The formalization below follows Filardo (1994), Filardo and Gordon (1998), Laton and Smith (2007), Kim et al (2010).

Suppose that $\mathrm{y}_{\mathrm{t}}=\mu\left(\mathrm{s}_{\mathrm{t}}\right)+\varnothing\left(\mathrm{s}_{\mathrm{t}}\right) \mathrm{y}_{\mathrm{t}-1}+\sigma \varepsilon_{\mathrm{t}}, \quad \varepsilon_{\mathrm{t}} \sim \mathrm{N}(\mathrm{o}, 1)$

$\mathrm{S}_{\mathrm{t}}=\{0,1\}$ is a latent variable and $\mu\left(\mathrm{s}_{\mathrm{t}}\right)=\mu_{1}+\mu_{2}\left(\mathrm{~s}_{\mathrm{t}}\right), \varnothing\left(\mathrm{s}_{\mathrm{t}}\right)=\emptyset_{1}+\emptyset_{2}\left(\mathrm{~s}_{\mathrm{t}}\right)$.

$\mu\left(\mathrm{s}_{\mathrm{t}}\right)$ and $\varnothing\left(\mathrm{s}_{\mathrm{t}}\right)$ indicate that the average value of FSI and its autoregressive dynamic is regime-dependent.

Equation (2) can be generalized in order to include higher lags and a state-dependent residual standard error.

Since $s_{t}$ is assumed to follow a Markov-chain, the realization of each state is assigned a probability and the transition probability matrix is written as follow:

$\mathrm{P}\left(\mathrm{s}_{\mathrm{t}}=\mathrm{i} / \mathrm{s}_{\mathrm{t}-1}=\mathrm{j}, \mathrm{It}\right)=\left(\begin{array}{cc}p\left(I_{t}\right) & 1-p\left(I_{t}\right) \\ 1-q\left(I_{t}\right) & q\left(I_{t}\right)\end{array}\right), \mathrm{i}, \mathrm{j}=1,2$

Where $\mathrm{I}_{\mathrm{t}}=\left\{\mathrm{L}_{\mathrm{t}}, \mathrm{L}_{\mathrm{t}-1} \ldots\right\}$ is the history of the leading indicator of the financial stress index (financial globalization variable). This formalization assumes that a country's financial openness to international financial market is informative with regard to the likelihood of a higher or a lower financial stress.

The functional form of the function $\mathrm{p}($.$) and \mathrm{q}($.$) is assumed to be sigmoid and to map the$ leading indicator values into the $[0,1]$ interval (logistic, Gaussian, Cauchy distributions).

We assume here a logistic function, as is common wisdom in the empirical literature using this class of models.

$$
p\left(I_{t}\right)=\frac{\exp \left(\theta_{0}^{p}+\sum_{m=1}^{M} \theta_{m}^{p} L_{t-m}\right)}{1+\exp \left(\theta_{0}^{p}+\sum_{m=1}^{M} \theta_{m}^{p} L_{t-m}\right)}, \quad q\left(I_{t}\right)=\frac{\exp \left(\theta_{0}^{q}+\sum_{m=1}^{M} \theta_{m}^{q} L_{t-m}\right)}{1+\exp \left(\theta_{0}^{q}+\sum_{m=1}^{M} \theta_{m}^{q} L_{t-m}\right)}
$$

Assume that the two states correspond respectively to a lower financial stress (state 0 ) and a higher financial stress (state 1). Then, we might have the following situations: 


\section{Case 1-}

The Debt (internal or/and external) variable doesn't expect about a future low or high financial stress. Since the model is a Hamilton (1991) model, and assuming $\sum_{m=1}^{M} \theta_{m}^{p} L_{t-m}$ and $\sum_{m=1}^{M} \theta_{m}^{q} L_{t-m}$, therefore $\mathrm{p}\left(\mathrm{I}_{\mathrm{t}}\right) \neq 0$ and /or $\mathrm{q}\left(\mathrm{I}_{\mathrm{t}}\right) \neq 0$, means that the FSI index evolves in two regimes, BUT there are other variables explaining this. If $\mathrm{p}\left(\mathrm{I}_{\mathrm{t}}\right)=\mathrm{q}\left(\mathrm{I}_{\mathrm{t}}\right)=0$, in this case, the dynamic of the FSI index is a linear AR(1) model and is not regime dependent.

\section{Case 2-}

If $\sum_{m=1}^{M} \theta_{m}^{p} L_{t-m}>0$, the positive sign of the indicator indicates an increase in the likelihood of a low financial stress regime $m$ quarters later.

If $\sum_{m=1}^{M} \theta_{m}^{p} L_{t-m}<0$, in this case, the negative sign of the indicator indicates a decrease in the likelihood of a low financial stress regime $m$ quarters later

\section{$\underline{\text { Case3- }}$}

If $\sum_{m=1}^{M} \theta_{m}^{q} L_{t-m}>0$, the positive sign indicates of the leading indicator indicates the increase in the likelihood of a high financial stress regime $m$ quarters later.

If $\sum_{m=1}^{M} \theta_{m}^{q} L_{t-m}<0$, the negative sign of the leading indicator indicates a decrease in the likelihood of a high financial stress regime $m$ quarters later.

\section{Case 4-}

If $\sum_{m=1}^{M} \theta_{m}^{p} L_{t-m}=0$ and $\sum_{m=1}^{M} \theta_{m}^{q} L_{t-m}>0(<0)$, the leading indicator indicates only the transition dynamic during the shifting from a low financial stress regime to a high financial stress regime (because $\left.\sum_{m=1}^{M} \theta_{m}^{p} L_{t-m}=0\right)$. If the shift is positive $\left(\sum_{m=1}^{M} \theta_{m}^{q} L_{t-m}>0\right)$, the indicator predict whether there is an increased or reduced likelihood of observing a high financial regime $m$ periods later ONLY when the economy is already in a financial stress regime.

\section{Case 5-}

If $\sum_{m=1}^{M} \theta_{m}^{p} L_{t-m}>0(<0)$ and $\sum_{m=1}^{M} \theta_{m}^{q} L_{t-m}=0$, the leading indicator indicates only the transition dynamic during the shifting from a high financial stress to a low financial stress. 
The sign of the leading indicator predict the likelihood of a low stress regime ONLY if the economy is already in that regime.

Assuming data and information we use in our model, cases 4 and 5 illustrate, if a financial stress situation can be avoidable or if a low financial situation will be welcomed.

In this study, parameters of equations 2, 3, and 4 are estimated jointly by using maximum likelihood ${ }^{7}(\mathrm{ML})$, as shown below because of its computational ease. In fact, ML yields consistent and asymptotically efficient estimates in case if errors are normally distributed ${ }^{8}$. The inverse of the matrix of second partial derivatives of the likelihood function computed at the true parameter values is a consistent estimate of the asymptotic variance-covariance matrix of the parameter values.

\section{IV- Results and Interpretation}

\section{A-Preliminary test and parameters understanding}

Before estimating our model, we should be sure of the stationarity of all our variables. Therefore, we tested them with the ADF test and results are reported in appendix 2, table 1. All variables reported a strong stationary level. However, some of them such as: - TED/GDP, STED/TED and IR/TED in Turkey,-STED/GDP, TED/GDP, IR/TED and IR/GDP in RussiaTED/GDP and STED/IR in Argentina, - STED/GDP, TED/GDP and IR/GDP in Brazil, - and finally STED/TED and IR/GDP in Mexico, were placed in lag 1 (First differential) in order to have a stronger stationarity level.

Perlin (2012) and Zhuanxin Ding (2012) utilized MATLAB Package to estimate the Markow Regime Switching Models with time varying. In this present study, we have utilized the same MATLAB package as per Perlin (2012) and Zhuanxin Ding (2012) and reported the following results in appendix 3, table 1 to table 5. In order to gauge the robustness of estimations, we applied the test on expected residuals, such the JB test, test the null hypothesis of no serial correlation of order 1 and 4, and test of remaining nonlinearities. In addition, we applied the Ljung and Box test. The Ljung and Box test assesses the null hypothesis that a series of residuals exhibits no autocorrelation for a fixed number of lags L (=10 in our test), against the alternative that some autocorrelation coefficient $\mathrm{p}(\mathrm{k}), \mathrm{k}=1$.., $\mathrm{L}$, is nonzero . The test statistic is:

\footnotetext{
${ }^{7}$ In contrary to Diebold et al (1994) and Filardo and Gordon (1998) who used the EM algorithm or the Gibbs Sampler for their estimation ${ }^{8}$ See Kiefer (1978).
} 
$\mathrm{Q}=\mathrm{T}(\mathrm{T}+2) \sum_{k=1}^{L}\left(\frac{p(k)^{2}}{T-k}\right)$

Where $\mathrm{T}$ is the sample size, $\mathrm{L}$ is the number of autocorrelation lags, and $\mathrm{p}(\mathrm{k})$ is the sample autocorrelation at lag $\mathrm{k}$. Under the null, the asymptotic distribution of $\mathrm{Q}$ is chi-square with $\mathrm{L}$ degrees of freedom. Vector of Boolean decisions for the tests, with length equal to the number of tests. Values of $\mathrm{h}$ equal to 1 indicate rejection of the null of no autocorrelation in favor of the alternative. Values of $\mathrm{h}$ equal to 0 indicate a failure to reject the null.

Our estimations results are reported in table 1 to table 5 of appendix 3. The regression analysis includes one lag of the EM-FSI index and an intercept that are assumed to be regime dependent. The different sign of the intercept (negative and positive) indicates the discrimination of the 2 regimes in the EM-FSI index by the model. Usually, one corresponds to a negative sign and the other to a positive sign.

Indeed, the ratio $\mathrm{E}\left[\mathrm{y}_{\mathrm{t}}\right]=\frac{\mu\left(\mathrm{s}_{\mathrm{t}}\right)}{1-\emptyset\left(\mathrm{s}_{\mathrm{t}}\right)}$ gives the conditional expectation of the endogenous variable in each regime.

When both intercept are non significant, this means that the model fails to identify 2 regimes. Thus we can conclude from our estimations, that when the positive value of the intercept is statistically significant, it is usually higher than 1.5 , this indicating a high financial stress period or a crisis.

In order to interprete if our leading indicators have a predictive power for the 2 regimes of high and low stress after " $m$ " quarters, we have to focus first, on the parameters $\theta_{m}^{p} s$ which is informative about the predictive power in regime 1 (low stress) and second, on the parameter $\theta_{m}^{q} s$ which is informative about the predictive power in regime 2 (high stress).

\section{B- The power of debt and International reserves in predicting high/low financial stress.}

The FSI of our 5 representatives countries are reported in Appendix 1; figure 1. This latter shows the FSI trend of Turkey, Mexico, Russia, Brazil and Argentina with Turkey and Russia on the top because of their extreme degree. They all suffer at the same period from a high financial stress from 1998 to 2002, in 2004 and in 2008, where the peak is more important than other peak of other high stress period,, resulting in more severe and dangerous crisis. 
The decreasing trend of the FSI indicates that those countries have enjoyed some periods of low financial stress in 2000s, especially from 2003 to 2004 and from 2004 to 2008 (where 2004 was a peak of a high financial stress). Indeed, whether the experiences of previous banking crises, or stock market crashes, or oil crisis or real estate (2007-2008), they are evidence of the domino effects and the correlation between these aspects mentioned above. The similar FSI trend results from the interactions of financial market of different countries and/or thus the contagion effect especially in financial openness like the Asian crisis in 1997 that was extent to Argentina, Brazil and Russia. The common point of crisis in all these countries was the Forex: Exchange rate regime (currency board, Domestic currency pegged to the dollar) or shift of the exchange rate regime, interest rate, depreciation of the domestic currency and other reasons as: unsustainable debt, inflation, trade balance, etc.

As shown in this figure 1, all these countries suffered at least two sever financial crisis and enjoyed some period of low financial stress. In addition, they all have the same characteristics where they both increase external debt and international reserves which justify the choice of these five 5 countries as a sample for the present study.

As mentioned earlier, the figure 1 shows period of low financial stress, were FSI index is below the average (1.5) and all countries have similar trend in calm period (with different degree).

Therefore, the FSI index is useful to quantify the degree of intensity of a higher or lower stress, which is important for policy purpose. Decisions and measures taken by the Central Bank, and monetary authority should take into consideration the turning point in the index in order to detect business cycle and avoid and prevent upturns crisis.

\section{1-The case of Turkey}

The results of our estimations of Turkey are reported in the appendix 3, table 1.

As shown by the parameters, all leading variables are informative except for the STED/TED, where neither $\theta^{\mathrm{Pt}}$ nor $\theta^{\mathrm{Qt}}$ are statistically significant.

Starting with the Total external debt, we found that TED/GDP is informative in two states, two regimes. In fact, as shown in the column 2 of table 1, an increase of TED/GDP can increase the likelihood of observing a high financial stress two quarters later, and this is indicated by the positive sign and the statistic significant of the $\theta^{\mathrm{Qt}}$. This variable held to predict low financial stress too since its $\theta^{\mathrm{Pt}}$ is negative and statistically significant. Therefore, this variable should be very informative and one of the main tool for the monetary authority in 
their policy decision since its variation can predict both, a high and a low financial stress by shifting from one regime to another. As for the Short term external debt, both, STED/GDP and STED/IR are informative, but the latter, the Grennspan-Guidotti ratio gives more sense since it gives prediction too in two regimes: in low financial stress and high financial stress. Indeed, a decrease of STED/IR can insure a low financial stress two quarters later, even in period of stress, since the opposite side is significant, and since the increase of STED/IR can increase the likelihood of observing a high financial stress two quarters later. The STED/GDP gives the same conclusion only in one regime, in the regime of low stress, where the $\theta^{\mathrm{Qt}}$ is positive and thus, can be an powerful indicator to predict a future low financial stress after two quarters if the STED/GDP decreases.

Concerning the IR, both IR/TED and IR/GDP are informative and give prediction only in one state, the state of low financial stress. Thus, the positive sign of the $\theta^{\mathrm{P}}$ which is statistical significant, indicates that an increase of the IR, relatively to TED and GDP can provide peace in the Turkish economy within two quarters, but the decrease of the IR will not necessarily cause a crisis.

Our results are in agreement with the economic situation of Turkey, in fact, as seen earlier in the figure 1 of appendix 1, the FSI of Turkey follows the same trend of all other countries, but with an extreme top whether it is in one state or the other. Indeed, Turkey is very vulnerable to external debt, and is heavily indebted in foreign currency. It should be noted that before the most severe financial crisis for Turkey, and since 1994, Turkey was increasing it short term external debt, in addition, it did new external debt engagement of 66 Billion of US dollar in 1996 and 100 Billion US dollar in 1999, thus increasing in country's risk premium. In 2000, just before the short term foreign debt has increased significantly and Turkey has been thriving on a borrowing boom. In the other side, in 2000, in order to defend the currency more robustly from outset, Turkey was using the central bank reserves. Therefore, this was in the heat of a incipient financial crisis. Later on, since the Transition of Strong Economy Program TSEP supported by the IMF and the World Bank in 2001, consisting of reducing the ratio of domestic debt/GDP and external debt/GDP, we can see that Turkey recognized a low financial stress, which is in agreement with our results discussed above. As well as for IR, in 1996, the central Bank of Turkey announced an important increase of IR in order to keep the exchange rate stable. Most of IR was the result of financing the increase in foreign assets. In 2008 ,even if the subprime crisis was transmitted to Turkish economy as well as to all emerging countries, the impact of the global financial crisis on the Turkish economy have 
been fairly limited thanks to the healthy banking sector, prudent fiscal and monetary policy stance, floating exchange rate and of course to the strong accumulation of international reserves.

\section{2-The case of Russia}

Results of the case of Russia are reported in appendix 3, table 1. Only three variables with debts make sense, in other terms, IR/TED and IR/GDP are not significant, neither STED/TED although all intercept are. Starting with STED/GDP, we can see that $\theta^{\mathrm{Pt}}$ is negative and significant a $10 \%$. As for TED/GDP while it is not considered at significant, because it is at $14 \%$, its negative sign seems logical with the economic interpretation. In fact, for both variables, a decrease in debt can insure a low stress in the Russian economy two quarters later. An increase in STED/GDP or the TED/GDP doesn't mean necessarily an increase of the likelihood of having a financial crisis.

What is important to discuss in this case, like for the previous case of turkey, the GrennspanGuidotti rule is informative in both states since both $\theta^{\mathrm{Pt}}$ and $\theta^{\mathrm{Qt}}$ are statistically significant and their sign give logical conclusion. In fact, a decrease of STED/IR provides information of having a future low stress, while a decrease can predict a high financial crisis. In this case, this variable STED/IR should be taken into consideration by monetary authority since any variation can shift from one regime to another. This variable indicates how Russian economy is sensitive to any variation of debt. In fact, our results seems to be in agreement with the past history: in 1998, difficulties in implementing fiscal reforms aimed at raising government revenue and a dependence on short-term borrowing to finance budget deficit let to a serious financial crisis in 1998, contributing to a sharp decline in Russia's earning from oil exports and resulting in an exodus of foreign investors. As well as for the crisis period of 2008, when Russia was suffered by the subprime crisis due to it contagion effect, thus, a depleting in the reserve about 100 billion Rubles, what causes a worse casein liquidity than that of 1998. In addition to the withdraw of IR, the external debt were increasing sharply, which made Russian economy more and more vulnerable to crisis.

As for the STED/GDP, it should be noted that during the period 2000-2007 under the Putin's government, when the short term debt were maintain, in cooperation with the IMF, building up a Central Bank reserves with government budget, trade and current account surplus, the Russian economy has seen a peace economic years, characterized by a big economic growth. 
IR variables don't give sense in our analysis; this means they cannot detect low and/or high financial stress, thus, hoarding international reserves may not be a primordial monetary policy like for some other emerging countries. But since STED/IR is significant in both states (low and high financial crisis), this reinforce the past experience where the immediate cause if the 1998 crisis of Russia were the accumulation of STED in the form of treasury bills and bonds and the sharp decline of the IR between July 1998 and august 1998 (4.9\%).

\section{3-The Case of Argentina}

In Argentina, the STED/GDP, the TED/GDP and the STED/TED showed in Appendix 3, table 3, are informative only in one state: the high stress regime. They can be responsible for increasing the likelihood of having a high financial crisis after four quarters, two quarters and 3 quarters respectively. This is showed by $\theta^{\mathrm{Qt}}$ which is statistically significant with a positive sign. In fact, the positive sign of $\theta^{\mathrm{Qt}}$ indicates that an increase of the leading variable (STED/GDP, TED/GDP, and STED/TED) will increase the likelihood of observing a financial crisis. These results are in parallel with economic theory and logical where the increase of these variables makes the economy vulnerable to crisis. Especially according to Calvo \& Reinhart studies from several years,

Indeed, in the previous period of the main crisis of argentine (1998 \& 2002), as shown below in the figure - $a$-, the STED/GDP and the TED/GDP increased greatly. In fact, in 90s, before the crisis, Argentina was increasing its liabilities in foreign currency and in short term maturity without improving is export. Thus, the economy becomes depending on foreign currency, thus, the capital flight and sudden stop make Argentina vulnerable to crisis. In fact, in 1995, the foreign debt was unsustainable and has made it difficult for the nation to maintain currency convertibility, economic growth during that period. Later, in 2001, Argentine debt, held mostly in bonds, was massively sold short and the government found itself unable to borrow or meet debt payments. 


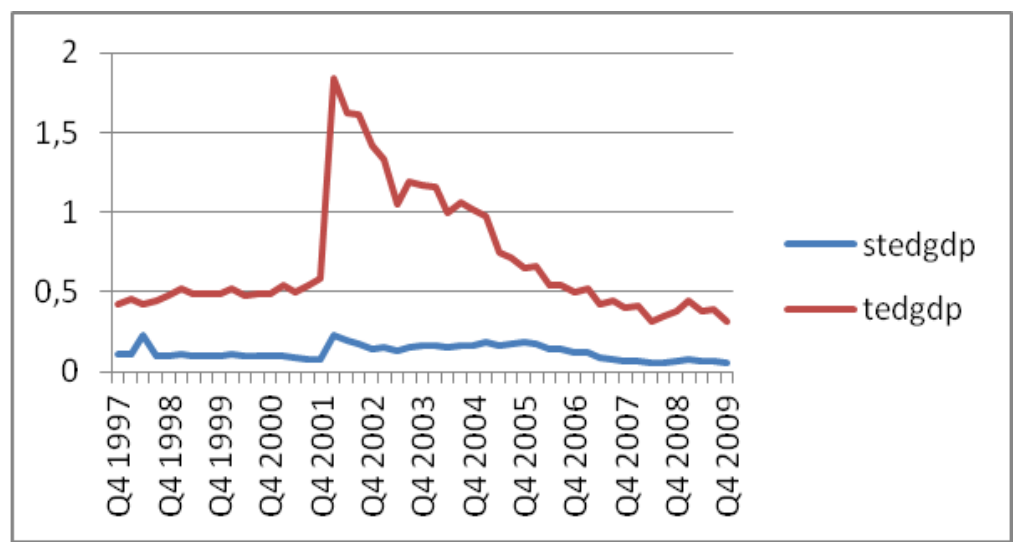

If results showed that increasing of foreign debt are good indicators to predict future financial crisis, their decrease doesn't justify it. In fact, because $\theta^{\mathrm{Pt}}$ are not significant in all of these cases, this indicates that a decreasing of foreign debt does not mean necessarily to insure a low financial stress, especially of the country in already in a crisis. Therefore monetary authority should focus their objectives on how to maintain the level of External debt in order to avoid a future financial crisis by cooperation to other economic policy, but not mainly how to decrease debts to insure economic peace. In 2008, during the international crisis, the debt Argentina re-entered international debt. Venezuela holds an estimated US $\$ 6$ billion in Argentina debt. Moody's boosted Argentina's debt rating to B from B-

As for IR variables, such the STED/IR, the IR/TED and the IR/GDP, the first one is not significant, since none of $\theta^{\mathrm{Qt}}$ and $\theta^{\mathrm{Pt}}$ is significant. As for IR/TED and IR/GDP, results seem to be interesting to analyze.

In fact, results indicate that any decrease of the IR whatsoever relating to total external debt or to GDP, this will increase the likelihood in Argentina to have financial crisis. The opposite conclusion doesn't hold up, and an increase of IR will not guarantee to increase the likelihood of having low financial crisis. In fact, this is what history told us. The IR has an important increasing trend, from 90s, but albeit this, Argentina suffered from several crisis, and this increasing trend didn't insure peace of the economy. We conclude that the IR is important in the economy of Argentina in order to avoid future financial crisis, but doesn't afford economic peace, although the increasing trend of IR. This might be due to the cost of IR which is not always sustainable, and may be due to the sterilization of IR policy that has cost and application constraints.

\footnotetext{
${ }^{9}$ Reference : author calculations and the International Financial Statistics IFS-IMF
} 


\section{4- The Case of Brazil.}

Unlike the case of Argentina, in Brazil, external debt (short term or total external debt), whether measured on GDP or on IR, they are not good predictor of high financial stress. Indeed, our results in Appendix 3, table 4 shows that non of $\theta^{\mathrm{Qt}}$ of these 3 variables are significant. Only $\theta^{\mathrm{Pt}}$ are positive and statistically significant. Whether for STED/GDP or for TED/GDP or STED/IR (Grennspan-Guidotti rule), they all indicate an informative role of observing an economics peace two quarters later, thus a low financial stress. The negative sign of the parameter indicates that a decrease of these leading variables will increase the likelihood of the economy of Brazil to testify a low financial stress. But the opposite conclusion is not informative, in other way, an increase of external debt does not necessary induce the economy to a financial crisis. The government of Brazil, in order to avoid future financial crisis should more focus on other economic variables than External debt (such currency stability, inflation, balance of payment etc..), and in order to maintain a low peace economic period. Brazil should focus on reducing its external debt. (cf the figure $-b$-). Note that STED/TED is not informative.

\section{Figure - $b$ - The short term external debt on GDP, Total external debt o GDP, and FSI from}

\section{7 to $2010^{10}$}

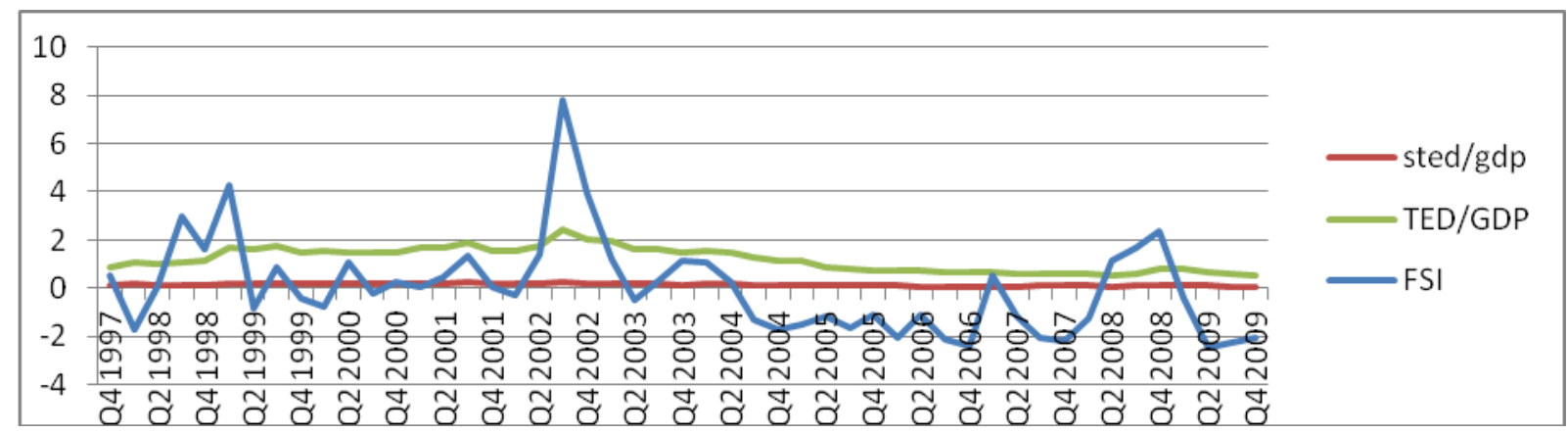

Indeed, at the end of 90s, Brazil was more affected by Asian crisis when investors became more risk averse to (merging country). But Brazil was helped by the IMF in 1998 with 4.5 Billion US dollar. One month later the real was devaluated and Brazil announced that its currency wills no more be pegged to US Dollar with an international support and in 1999 in order to maintain tight fiscal and monetary policy. Brazil knew difficult period concerning its inflation, its current account deficit, but not its external debt.

\footnotetext{
10 Reference : author calculations and the International Financial Statistics IFS-IMF
} 
As for the IR, only IR/TED is statistically significant with a positive value of $\theta^{\mathrm{Qt}}$. The IR/GDP is not informative since non of $\theta^{\mathrm{Pt}}$ and $\theta^{\mathrm{Qt}}$ are statistically significant.

The IR/TED indicates that a decrease of International reserves relatively to Total External Debt can be predictable to a future financial crisis. This result is in agreement with the economic theory where IR should be relatively high to cover External debt in case of any currency crisis or capital flight, especially in country that suffered from financial crisis and where the trust is not complete, any uncertain period will led to a capital flight and flight to quality.

\section{5-The case of Mexico}

The tables 5 of appendix 3 shows that all variables used in our estimations are representatives except for the variable IR/GDP where $\theta^{\mathrm{Pt}}$ and $\theta^{\mathrm{Qt}}$ are not statistically significant.

Similar to the case of Mexico, all of representatives' variables are significant and predictable only in low financial stress, even the IR/TED variable, where for Brazil; it was the only variable that can predict a future financial crisis.

In fact, as seen in the table 5 , for all variables, the $\theta^{\mathrm{Pt}}$ are statistically significant within two quarters later. This means that External debt and International reserves can be good predictors for the government only to predict a low financial crisis. Because the opposite case in not significant, we can deduce that, if Mexico is inside a severe crisis, a decreasing of STED/GDP, or TED/GDP, or STED/TED and STED/IR cannot insure a low stress. The decrease of these variables may insure a future low financial stress. Our results are in agreement with the history of Mexico. In fact, Mexico is vulnerable to any imbalance is the domestic currency and inflation. It is after the devaluation of $50 \%$ of the Mexican peso (domestic currency) in 1994 that Mexico suffered from a collapse of its stock market, and later on, after the government has decided to float the peso against the US Dollar, the interest rate has increased and IMF intervened in order to help Mexican economy.

As for the IR and increase of the IR/TED will insure the Mexican economy a low stress period, but the decrease will not necessarily induce a high financial stress. In fact, Mexico, whether is doing effort to maintain low its inflation rate enjoying the FDI and its free market economy, it is suffering from a deficit of the trade balance and current account. Thus, according to the literature, an increase of IR/TED can be a kind of a sudden stop. Thus the role of the auto insurance of the IR. 


\section{V-Summary}

Our results show that not all variables can be useful for monetary authority in both period of high financial stress and low financial stress. None of our leading indicator could be informative as a turning point from one regime to another. In turkey, our results seem to be very strong. The external debt (short term and total external debt) are very informative and in both states. Thus, Decision of monetary authority should take into consideration the level of external debt whether they are in low financial stress or high financial stress; because of its power of predicting future change in both regimes. As for the IR, it plays the role of being the buffer stock and insurance to provide peace in the economy, but its absence or decrease will not trigger a financial crisis. The increases of IR reserves play a role of insuring a low financial stress but its decrease cannot inform any future financial crisis.

In the case of Russia, the Grennspan-Guidotti rule is informative in both states. In fact, a decrease of STED/IR provides information of having a future low stress, while a decrease can predict a high financial crisis. In this case, this variable STED/IR should be taken into consideration by monetary authority since any variation can shift from one regime to another. This variable indicates how Russian economy is sensitive to any variation of debt. IR variables don't give sense in our analysis; this means they cannot detect low and/or high financial stress, thus, hoarding international reserves may not be a primordial monetary policy like for some other emerging countries. But since STED/IR is significant in both states (low and high financial crisis), this reinforce the past experience where the immediate cause if the 1998 crisis of Russia were the accumulation of STED in the form of treasury bills and bonds and the sharp decline of the IR between July 1998 and august 1998 (4.9\%).

As for Argentina, debt variables and IR variables can't be a strategy for the government during a crisis. In other terms, when Argentina is suffering from a financial crisis, a decrease of debt and/or an increase in IR is not necessary a good decision to reduce the financial stress. The government should have recourses to other economic variables in order to mitigate the situation. On the other side, when Argentina is enjoying a low financial stress, a decrease of IR and/or an increase in Debt are significant and so should be monitored. These variables increase the likelihood of observing high financial stress within a year and thus, should always be the focus of the government in order to keep low financial stress situation. 
As for Brazil, our results conclude that crisis is not due mainly to high external debt, and its increase does not necessarily increase the likelihood of observing financial crisis. On the other side, having a sustainable level of debt or a decreasing trend can be a good predictor to a future low financial stress. The IR reserve can be a tool for the monetary authority to avoid financial crisis since its decrease can predict a high financial stress. Therefore government of Brazil may rather focus on other economic variables such currency stability, inflation rate, balance of payment etc... In order to avoid future financial crisis and it should focus on keeping the International reserves high in order to insure stability and economic peace.

The case of Mexico, none of the studied variables can predict a future financial crisis, but they can insure a low financial crisis. Therefore, the government of Mexico, should not focus on Debt to avoid future financial crisis, but can use IR as a tool to maintain a low financial stress.

\section{VI- Conclusion}

Based on the results we obtained, we can conclude that the Leading Indicators studied, either IR or ED, are not necessarily all of significant, and therefore do not constitute for monetary authorities a main tools or decisions to handle.

Indeed, if the rise and / or decrease in external debt is significant to increase or to avoid the likelihood of future financial crises for Turkey, Russia, Argentina and Brazil, it is not for Mexico.

Similarly, if increasing and / or decreasing International Reserves is significant in the increases and / or decreases the likelihood of financial crises in Turkey, Russia and Brazil, it is less so in Argentina and not in Mexico.

although countries chosen have common points such being emerging countries, accumulating international reserves, increasing external debt and having suffered from severe financial crisis in the end of 90 s and the beginning 2000s, results are different from a country to another and this is due to the difference in the economic environment that makes the country more or less susceptible to financial crises during the variation of Leading Indicators. 


\section{References}

Aizenman J, Lee J W, 2010, Hoarding International Reserves Versus a Pigovian TaxCumb-Subsidy Scheme; USCS and NBER Working Paper, $N^{\circ} 15484$

Aizenman J, Jinjarak Y, Park D; 2010; “International Reserves ans Swap Lines: Substitutes or Complements?”; NBER Working Paper, $\mathrm{N}^{\circ} 15804$.

Aizenman J; 2009; "On the Paradox of Prudential Regulations in the Globalized Economy, International reserves and the Crisis: a Reassessment”; NBER Working Paper, $\mathrm{N}^{\circ} 14779$

Aizenman J, Lee J W; 2008;'Financial versus Monetary mercantilism-Long Run View of Large International reserves Hoarding; World Economy $\mathrm{N}^{\circ} 31$.

Aizenman J, Lee J W; 2007; International reserves: precautionary versus mercantilist vews, theory and evidence", Open Economies Review, 18(2), pp.191-214

Aizenman J, Marion N; 2004; International Reserves Holding with Sovereign risk and costly tax collection", Economic Journal 114, pp 569-591.

Balakrishnan R, Dnninger S, Tytell I ; 2009 ; «the transmission of financial stress from,advanced to emerging economies », IMF Working paper 09/133.

Bekaert G, Harvey C.R, Lundbld C; 2005; "Does financial liberalization spur growth?", Journal of Financial Economics, Vol 77, Issue1, pp.3-55.

Ben Grama S, Clévenot D; 2007; "Politique et libéralisation financière et crises bancaires ; Economie Internationale ; $4^{\text {ème }}$ trimestre, $\mathrm{N}^{\circ} 112$.

Bénassy-Quéré A, Salins V; 2005; “Impact de l'ouverture financière sur 1s inégalités dans les pays émergents, CPEI, Document de travail $N^{\circ} 2005-11$.

Ben-Brassat A, Gottlied D ; 1992 ; "Optimal International Reserves and Soverign Risk", Journal of International Economics 33, pp.345-362.

Benmelech E, Dvir E; 2011, Does Short-Term Debt Increase Vulnerability to Crisis? Evidence from the East Asian Financial Crisis, NBER Working Paper $N^{\circ} 17468$

Caballero R, Krishnamurthy A ; 2001 ; « International and Domestic Collateral Constrains in a Model of Emerging Market crisis », Journal of Monetary Economics, 48(3), p.513-548.

Ciarlone A, Trebeschi G; 2005; Designing an early warning system for debt crises; Emerging Market review; Vol 6 Issue 4; pp. 376-395.

Calvo G; 2006; “ Monetary Policy challenges in Emerging Markets: sudden stop, Liability dollarization, and lender of last resort; NBER Working Paper $\mathrm{N}^{\circ} 12788$

Calvo G, Mishkin F; 2003; The mirage of Exchange rate regimes for emerging market countries; The Journal of Economic Perspectives, Vol. 17, No. 4, pp. 99-118.

Calvo G, Reinhart C; 2002; fear of floating; quarterly Journal of Economics 117; pp379408. 
Calvo C, Guillermo, Reinhart C; 2000; "Fixing for Your Life,"NBER Working Papers, NBER Working Paper Nº 8006

Calvo G; 1991; The Peril of Sterilization; IMF Vol.38, N4

Cheung Y-W, Ito H ; 2009 ; « Cross Sectional Analysis on the determinant of International Reserves Accumulation, International Economic Journal, 23(4):447-481,

Dominguez K, ME, 2009, International reserves and Underdeveloped Capital Market, Univesity of Michigan and NBER, discussion pape $\mathrm{N}^{\circ} 600$

Dufrénot G, Furceri D, Zdzienicka A; 2011; Financial Globalization and Financial Stress in Latin America: The case of Argentina, Brazil and Mexico.

Eichengreen B, Bordo M D; 2002; Crisis now and then: what lessons from the last era of financial globaalization; NBER working papr $\mathrm{N}^{\circ} 8716$

Eichengreen B, Hausmann R; 1999, Exchange Rate and Financial Fragility; NBER Working Paper $\mathrm{N}^{\circ} 7418$.

Goldstein M, Kaminsky G L, Reinhart C M ; 2000 ; Assessing financial vulnerability; an early warning system for emerging Markets; Peterson Institute; Institute dor International Economics, ISBN 0-88132-237-7

Hoxha I, Kalemli-Ozcan S, Vollrath D; 2009; "How big are the gains from International Financial integreation?”, NBER Working Paper N 1436.

Kaminsky G L; 2007, Crises of sudden stop: evidence from International bond, and syndicated loan market; George Washington university and NBER

Kaminsky G.L, Smuckler S.L; 2002; "Short run pain, long run gain: the effect of financial liberalization, World Bank Policy Research, Working Paper Nº 2912.

Kaminsky G L, Reinhart C M, 1999; The twin crises: the causes of banking and blance of paayment problems, The American Economic Review.

Kaminsky G, Lizondo S, Reinhart C; 1998; "Leading indicator of Currency Crisis" IMF Staff paper, Vol 45, pp 1-48.

Kose M.A, Prasade E.S, Terrones M.E ; 2008 ; « Does Openness to international financial flows raise productivity growth? NBER Working Paper $\mathrm{N}^{\circ} 14558$.

Laeven L, Valencia F; 2008; Systematic Banking Crises: a new database; IMFInternational Monetary Fund, Working Paper. 08/224.

Mishkin F; ; 2011; “Monetary Policy Strategy: Lessons from the Crisis"NBER Working Paper $\mathrm{N}^{\circ} 16755$

Mishkin F ; 2005 ; « Is Financial Globalization Beneficial ?” NBER Working Paper $\mathrm{N}^{\circ}$ 11891

Obsfeld M ; 2009 ; International Finance growth in developing Countries: what have we learned?" NBER Working paper $\mathrm{N}^{\circ} 14691$. 
Obsfeld M, Schaumbaugh J C, Taylor A M, 2009, Financial Instability, Reserves, and Central Bank Swap Lines in the Panic of 2008, NBER Working Paper, №14826

Obsfeld M, Schambaugh J.C, Taylor A.M; 2008; "Financial Stability, the trilemma and International Reserves, NBER Working Paper $\mathrm{N}^{\circ} 14217$.

Obstfeld M ; 2004 ; «Globalization, Macroeconomic performance, and the Exchange rate of emerging Economies » NBER Working Paper $N^{\circ} 10849$

Prasad E.S, Rogoff K, Wei S.J, Kose M.A ; 2004 ; « Financial Globalization growth and Volatirity in developing Countries” NBER Working Paper $\mathrm{N}^{\circ} 0942$.

Rajan R, Douglas W. D ; 2009 ; The credit crisis; Conjectures about causes and remedies; NBER Working Paper $N^{\circ} 14739$.

Rancière R, Tronell A, Westermann F ; 2006 ; « Decomposing the effects of Financial Liberalization : crisis vs growth; Journal of Banking and Finance, Vol 30, Issue 12, pp. $3331-3348$

Reinhart C. M ; 2010 ; This Time is Different Chartbook: Country Histories on Debt, Default, and Financial Crises; University of Maryland, NBER and CEPR

Reinhart C M, Rogoff K S,2009; The aftermath of financial crises, NBER Working Paper $\mathrm{N}^{\circ} 14656$.

Reinhart C.M, Rogoffn K.S; 2008; "Domestic Debt: the forgotten History"; NBER Working Paper $N^{\circ} 13946$

Reinhrad C, Tokatlidis I ; 2002 ; « Before and After financial libralization, paper presented in the world bank on financial globalization

Reinhart C; 2000; The Mirage of floating exchange rates "MPRA Paper $\mathrm{N}^{\circ}$ 13736, University Library of Munich, germany.

Rodrik D, Velasco A ; 1999; « Short Turm Capital Flow. NBER Working Paper Nº7464.

Vidon E, 2007; 'L'accumulation des réserves de change est elle un indicateur d'enrichissement d'une nation ? », Bulletin de Banque de France, $\mathrm{N}^{\circ} 161$

Williamson J et Mahar M; 1998; "A survey of Financial liberalization, essays in International finance, $\mathrm{N}^{\circ} 211$, Department of Economics and Princeton University. 
Figure 1. THE FSI of Turkey, Russia, Argentina, Brazil and Mexico from 1997 to 2010.

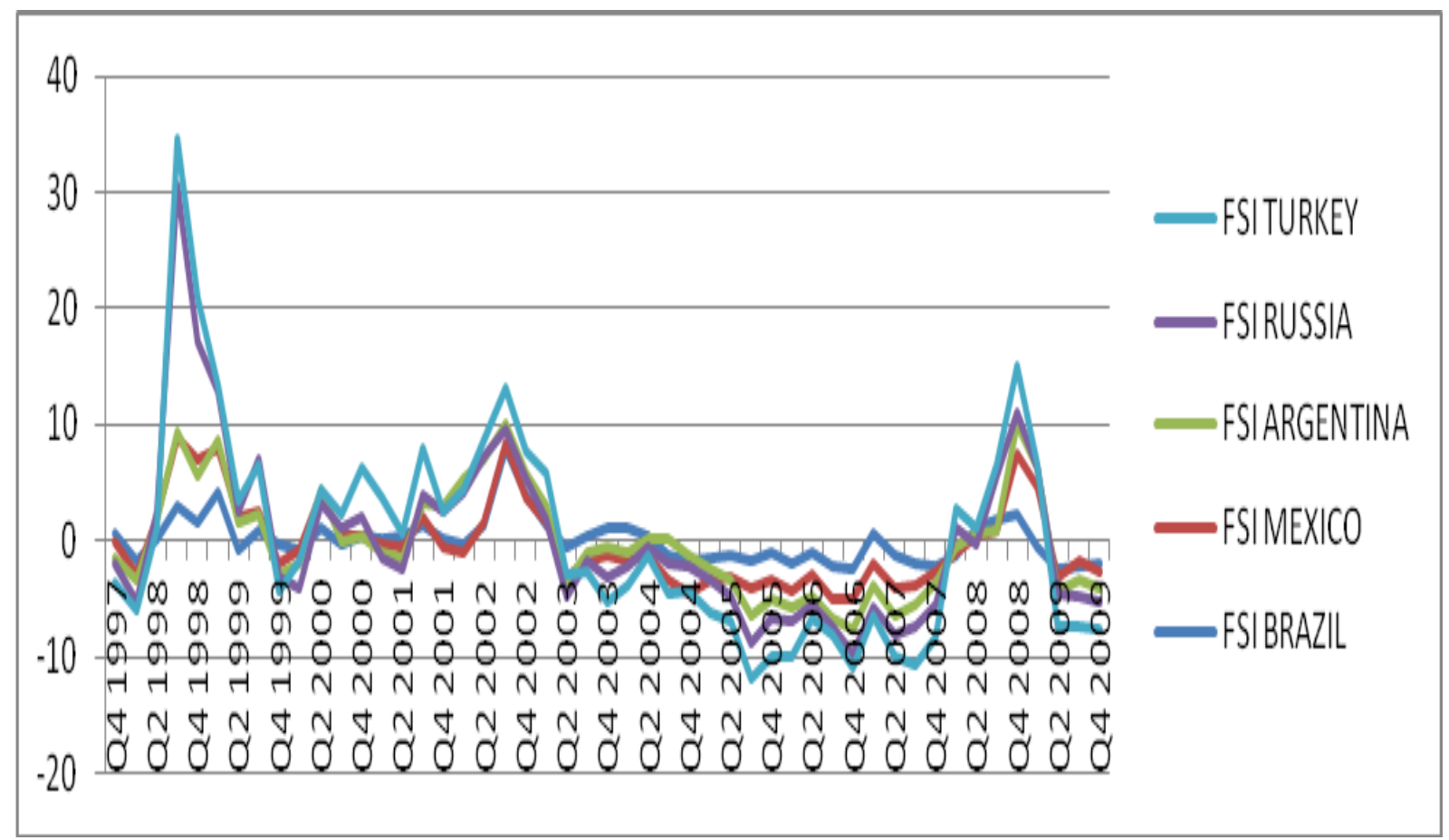

\section{Appendix 2}

Table 1-ADF TEST

\begin{tabular}{|l|l|l|l|l|l|l|l|}
\hline & FSI & STED/GDP & $\begin{array}{l}\text { TED/GDP } \\
\text { arg2 }\end{array}$ & $\begin{array}{l}\text { STED/TED } \\
\arg 3\end{array}$ & STED/IR & IR/TED & IR/GDP \\
\hline ARGENTINA & $-2.626^{* * *}$ & $-2.7413^{*}$ & $-7.5774^{* * *}$ & $-1.716^{*}$ & $-2.448^{* * *}$ & $-1.7825^{*}$ & $-2.6294^{*}$ \\
\hline BRAZIL & $-3.7156^{* * *}$ & $-8.704^{* * *}$ & $-7.6621^{* * *}$ & $-2.7655^{\circ}$ & $-2.1580^{* *}$ & $-3.591^{* *}$ & $-6.5659^{* * *}$ \\
\hline MEXICO & $-2.7859^{* * *}$ & $-2.7906^{* * *}$ & $-2.1923^{* *}$ & $-2.838^{* * *}$ & $-5.670^{* * *}$ & $-2.192^{* *}$ & $-5.6780^{* * *}$ \\
\hline TURKEY & $-2.944^{* * *}$ & $-2.624^{*}$ & $-6.58125^{* * *}$ & $-2.47321^{* *}$ & $-1.969^{*}$ & $-2.8081^{* * *}$ & $-3.8650^{* * *}$ \\
\hline RUSSIA & $-4.133^{* * *}$ & $-4.8904^{* * *}$ & $-2.86648^{* * *}$ & $-2.839^{\circ}$ & $-3.253^{\circ}$ & $-2.5989^{\circ}$ & $-4.497^{* * *}$ \\
\hline
\end{tabular}

${ }^{\circ}, *, * *, * * *$ indicate that value are statistically significant respectively at $10 \%, 5 \%, 1 \%$, and $0 \%$ 


\section{Appendix 3}

Table 1- Turkey

\begin{tabular}{|c|c|c|c|c|c|c|}
\hline & STED/GDP & TED/GDP & STED/TED & STED/IR & IR/TED & IR/GDP \\
\hline$\sigma$ & $0.65^{* * *}$ & $0.68^{* * *}$ & $0.72^{* * *}$ & $0.64^{* * *}$ & $0.75^{* * *}$ & $0.72^{* * *}$ \\
\hline$\mu_{1}$ & $-0.78 * * *$ & $-0.61 * * *$ & $-0.8 * * *$ & $-0.61 * * *$ & $-0.61 * * *$ & -0.6 \\
\hline$\mu_{2}$ & $3.13^{* * *}$ & $3.34 * * *$ & $3.11 * * *$ & $3.34 * * *$ & $3.34^{* * *}$ & $3.34 * * *$ \\
\hline$\mu_{1+} \mu_{2}$ & $2.35^{* * *}$ & $2.73 * * *$ & $2.31 * * *$ & $2.73 * * *$ & 2.73 & 2.74 \\
\hline$\emptyset_{1}$ & $0.59 * * *$ & $0.69 * * *$ & $0.61 * * *$ & $0.69 * * *$ & $0.69 * * *$ & $0.69 * * *$ \\
\hline$\emptyset_{2}$ & $0.32 * * *$ & $0.33^{* * *}$ & $0.35^{* * *}$ & $0.33 * * *$ & $0.33^{* * *}$ & $0.33 * * *$ \\
\hline$\emptyset_{1+} \phi_{2}$ & $0.91 * * *$ & 1.02 & $0.96 * * *$ & $1.02 * * *$ & 1.02 & 1.02 \\
\hline$\theta^{P 0}$ & $3.79 * * *$ & $1.897^{* * *}$ & $0.854^{* * *}$ & $2.12^{* *}$ & $-1.42^{*}$ & $0.325^{* * *}$ \\
\hline$\theta^{P 2}$ & 75.31 & $-0.619 *$ & -236.61 & $-0.04 * * *$ & $9.292 * *$ & $1.2805^{* *}$ \\
\hline$\theta^{\mathrm{P4}}$ & $-116.789 * * *$ & 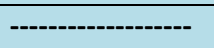 & -30.41 & $-0.057 * * *$ & 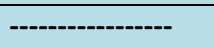 & --------------' \\
\hline$\theta^{Q_{0}}$ & $-0.189 *$ & 0.665 & 1.26 & -2.09 & 6.17 & 5.877 \\
\hline$\theta^{\mathrm{Q} 2}$ & -23.9 & $3.181 * * *$ & -57.81 & $0.71 * * *$ & 1.986 & 2.757 \\
\hline$\Theta^{Q_{4}}$ & 503.88 & 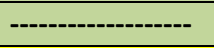 & 231.86 & 0.537 & -------------- & ------------ \\
\hline Log Liklihood & -83.624 & -91.101 & -81.254 & -92.075 & -90.2119 & -90.816 \\
\hline AIC & 191.244 & 198.203 & 186.51 & 208.1507 & 196.423 & 197.633 \\
\hline $\mathrm{BIC}$ & 213.70 & 213.172 & 208.965 & 230.8525 & 211.558 & 212.603 \\
\hline $\begin{array}{l}\text { Ljung-Box } \\
\text { Q-Test (10) }\end{array}$ & $\begin{array}{l}\mathrm{h}=0 \\
\mathrm{pV} \text { alue }=0.357 \\
\text { stat }=11.001 \\
\text { cValue }=18.307\end{array}$ & $\begin{array}{l}\mathrm{h}=0 \\
\mathrm{pV} \text { alue }=0.407 \\
\text { stat }=10.38 \\
\text { cValue }=18.307\end{array}$ & $\begin{array}{l}\mathrm{h}=0 \\
\mathrm{pV} \text { alue }=0.346 \\
\text { stat }=11.148 \\
\mathrm{c} \text { Value }=18.307\end{array}$ & $\begin{array}{l}\mathrm{h}=0 \\
\mathrm{pV} \text { alue }=0.15 \\
\text { stat }=14.425 \\
\text { cValue }=18.307\end{array}$ & $\begin{array}{l}\mathrm{h}=0 \\
\mathrm{pV} \text { alue }=0.5424 \\
\text { stat }=8.892 \\
\text { cValue }=18.307\end{array}$ & $\begin{array}{l}\mathrm{h}=0 \\
\mathrm{pV} \text { alue }=0.5007 \\
\text { stat }=9.334 \\
\text { cValue }=18.307\end{array}$ \\
\hline
\end{tabular}

$*, * *, * * *$ indicate that value are statistically significant respectively at $10 \%, 5 \%, 1 \%$,

Table 2- Russia

\begin{tabular}{|c|c|c|c|c|c|c|}
\hline & STED/GDP & TED/GDP & STED/TED & STED/IR & IR/TED & IR/GDP \\
\hline$\sigma$ & $0.85^{* * *}$ & $0.99 * * *$ & 0.86 & 0.94 & $0.88 * * *$ & $0.91^{* * *}$ \\
\hline$\mu_{1}$ & -0.55 & $-0.55 * * *$ & $-0.47 * * *$ & $-6.33 * * *$ & $-0.5^{* * *}$ & $-0.55 * * *$ \\
\hline$\mu_{2}$ & $14.61^{* * *}$ & $14.60 * * *$ & $13.81^{* * *}$ & $15.37^{* * *}$ & $14.33^{* * *}$ & $14.61^{* * *}$ \\
\hline$\mu_{1+} \mu_{2}$ & $14.06^{* * *}$ & $14.05^{* * *}$ & $13.34 * * *$ & $9.04 * * *$ & $13.83^{* * *}$ & $14.11^{* * *}$ \\
\hline$\varnothing_{1}$ & $0.5 * * *$ & $0.5 * * *$ & $0.49 * * *$ & $0.48 * * *$ & $0.5^{* * *}$ & $0.5 * * *$ \\
\hline$\emptyset_{2}$ & $7.74 * * *$ & $7.78 * * *$ & $10.17^{* * *}$ & $7.91^{* * *}$ & $8.22 * * *$ & $7.74 * * *$ \\
\hline$\emptyset_{1+} \phi_{2}$ & $8.24 * * *$ & $8.28 * * *$ & $10.66 * * *$ & $8.39 * * *$ & $8.72 * * *$ & $8.24 * * *$ \\
\hline$\theta^{\mathrm{PO}}$ & $2.21 * * *$ & $2.185^{* * *}$ & $1.158^{*}$ & $6.966 * * *$ & 14.9 & $2.12^{* * *}$ \\
\hline$\theta^{P 2}$ & $-0.16^{*}$ & $-0.42(p v=0.14)$ & 3.667 & $-5.010 * * *$ & 11.04 & -0.002 \\
\hline$\theta^{\mathrm{P3}}$ & 0.009 & 0.34 & -------------------- & ----------------- & -8.8 & 0.001 \\
\hline$\theta^{\mathrm{Q} 0}$ & 10.72 & $-2.98^{*}$ & 6.571 & 0.243 & -8.5 & -6.06 \\
\hline$\theta^{\mathrm{Q} 2}$ & -5.62 & -0.1 & 1.189 & 2.619* & -9.652 & 0.97 \\
\hline$\theta^{\mathrm{Q}^{3}}$ & 5.47 & 0.12 & -------------- & |-------------------- & 4.819 & 1.76 \\
\hline Log Liklihood & -89.292 & -87.22 & -95.071 & -110.517 & & -88.123 \\
\hline AIC & 198.585 & 194.22 & 206.142 & 237.034 & & 197.204 \\
\hline $\mathrm{BIC}$ & 217.502 & 213.445 & 221.75 & 252.644 & & 216.123 \\
\hline $\begin{array}{l}\text { Ljung-Box } \\
\text { Q-Test (10) }\end{array}$ & $\begin{array}{l}\mathrm{h}=0 \\
\mathrm{pV} \text { alue }=0.186 \\
\text { stat }=13.716 \\
\text { cValue }=18.307\end{array}$ & $\begin{array}{l}\mathrm{h}=0 \\
\mathrm{pV} \text { alue }=0.216 \\
\text { stat }=13.126 \\
\text { cValue }=18.307\end{array}$ & $\begin{array}{l}\mathrm{h}=0 \\
\mathrm{pV} \text { alue }=0.06 \\
\text { stat }=17.421 \\
\text { cValue }=18.307\end{array}$ & $\begin{array}{l}\mathrm{h}=0 \\
\mathrm{pValue}=0.326 \\
\text { stat }=10.636 \\
\text { cValue }=18.307\end{array}$ & $\begin{array}{l}\mathrm{h}=0 \\
\mathrm{pValue}= \\
\text { stat }= \\
\text { cValue }=18.307\end{array}$ & $\begin{array}{l}\mathrm{h}=0 \\
\mathrm{pV} \text { alue }=0.238 \\
\text { stat }=12.733 \\
\mathrm{cV} \text { alue }=18.307\end{array}$ \\
\hline
\end{tabular}

$*, * *, * * *$ indicate that value are statistically significant respectively at $10 \%, 5 \%, 1 \%$, 
Table 3-Argentina

\begin{tabular}{|c|c|c|c|c|c|c|}
\hline & STED/GDP & TED/GDP & STED/TED & STED/IR & IR/TED & IR/GDP \\
\hline$\sigma$ & $0.61^{* * *}$ & $0.57^{* * *}$ & $0.56 * * *$ & $0.6 * * *$ & $0.55^{* * *}$ & $0.56 * * *$ \\
\hline$\mu_{1}$ & $2.27 * * *$ & $1.84^{* * *}$ & $1.74^{* * *}$ & $1.86 * * *$ & $1.92^{* * *}$ & $1.45^{* * *}$ \\
\hline$\mu_{2}$ & $-0.40 * * *$ & $-0.5^{* * *}$ & $-0.51 * * *$ & $-0.47 * * *$ & $-0.49 * * *$ & $-0.61 * * *$ \\
\hline$\mu_{1+} \mu_{2}$ & 1.87 & $1.34^{* * *}$ & $1.23 * * *$ & $1.39 * * *$ & $1.43^{* * *}$ & $0.84^{* * *}$ \\
\hline$\emptyset_{1}$ & $0.61^{* * *}$ & $0.7 * * *$ & $0.73 * * *$ & $0.71 * * *$ & $0.09 * * *$ & $0.81 * * *$ \\
\hline$\emptyset_{2}$ & $0.47^{* * *}$ & $0.47^{* * *}$ & $0.08^{* * *}$ & $0.5^{* * *}$ & $0.5^{* * *}$ & $0.5^{* * *}$ \\
\hline$\phi_{1+} \phi_{2}$ & 1.8 & $1.17^{* * *}$ & $0.81 * * *$ & $1.21 * * *$ & $0.59 * * *$ & $1.31^{* * *}$ \\
\hline$\theta^{\mathrm{PO}}$ & 0.69 & -0.1705 & -2.163 & -12.22 & -0.298 & $2.51^{*}$ \\
\hline$\theta^{\mathrm{P2}}$ & -95.18 & 8.614 & -56.97 & 9.10 & -51.209 & -19.833 \\
\hline$\theta^{\mathrm{P3}}$ & & & 77.178 & & & \\
\hline$\theta^{\text {P4 }}$ & 46.5 & & & & & \\
\hline$\theta^{\mathrm{Q} 0}$ & $-1.42^{*}$ & $-1.777^{* * *}$ & $6.611^{* * *}$ & -1.14 & $-0.87 * * *$ & $1.22^{* * *}$ \\
\hline$\theta^{Q 2}$ & 22.191 & $114.61 *$ & -127.55 & 0.67 & $-54.58 *$ & $-65.60 * * *$ \\
\hline$\theta^{\mathrm{Q3}}$ & & & 91.20* & & & \\
\hline$\theta^{\mathrm{Q} 4}$ & 29.97* & & & & & \\
\hline Log Liklihood & -74.77 & -77128 & -73.071 & -76.084 & -74.3679 & -75.894 \\
\hline AIC & 173.555 & 170.565 & 170.142 & 168.1683 & 164.735 & 171.78 \\
\hline $\mathrm{BIC}$ & 196.256 & 185.700 & 192.844 & 183.308 & 179.705 & 190.707 \\
\hline $\begin{array}{l}\text { Ljung-Box } \\
\text { Q-Test (10) }\end{array}$ & $\begin{array}{l}\mathrm{h}=0 \\
\mathrm{pV} \text { alue }=0.925 \\
\text { stat }=4.435 \\
\mathrm{cValue}=18.307\end{array}$ & $\begin{array}{l}\mathrm{h}=0 \\
\mathrm{pV} \text { alue }=0.8301 \\
\text { stat }=5.8206 \\
\text { cValue }=18.307\end{array}$ & $\begin{array}{l}\mathrm{h}=0 \\
\mathrm{pV} \text { alue }=0.733 \\
\text { stat }=6.916 \\
\text { cValue }=18.307\end{array}$ & $\begin{array}{l}\mathrm{h}=0 \\
\mathrm{pV} \text { alue }=0.9169 \\
\text { stat }=4.5884 \\
\text { cValue }=18.307\end{array}$ & $\begin{array}{l}\mathrm{h}=0 \\
\mathrm{pV} \text { alue }=0.595 \\
\text { stat }=8.3394 \\
\text { cValue }=18.307\end{array}$ & $\begin{array}{l}\mathrm{h}=0 \\
\mathrm{pV} \text { alue }=0.912 \\
\text { stat }=4.655 \\
\text { cValue }=18.307\end{array}$ \\
\hline
\end{tabular}

$*, * *, * * *$ indicate that value are statistically significant respectively at $10 \%, 5 \%, 1 \%$,

Table 4-Brazil

\begin{tabular}{|c|c|c|c|c|c|c|}
\hline & STED/GDP & TED/GDP & STED/TED & STED/IR & IR/TED & IR/GDP \\
\hline$\sigma$ & $0.99 * * *$ & $0.9 * * *$ & $0.93^{* * *}$ & $0.61 * * *$ & $0.83^{* * *}$ & $0.99 * * *$ \\
\hline$\mu_{1}$ & -0.06 & -0.2 & $2.93^{* * *}$ & $-0.40 * * *$ & -1.41 & -0.14 \\
\hline$\mu_{2}$ & $12.04 * * *$ & $19.27 * * *$ & $-0.39 * * *$ & $2.81 * * *$ & -0.17 & $9.92 * * *$ \\
\hline$\mu_{1+} \mu_{2}$ & ------ & ------ & $2.54 * * *$ & 2.41 & -------- & -------- \\
\hline$\emptyset_{1}$ & $0.56^{* * *}$ & $0.46 * * *$ & $2.00 * * *$ & $0.47 * * *$ & $6.58 * * *$ & $0.52^{* * *}$ \\
\hline$\emptyset_{2}$ & $-3.01 * * *$ & $-8.79 * * *$ & $0.47^{* * *}$ & $2.10 * * *$ & $0.48^{* * *}$ & $-2.55 * * *$ \\
\hline$\phi_{1+} \phi_{2}$ & $-2.45 * * *$ & -8.33 & $2.047 * * *$ & $2.57 * * *$ & $7.06 * * *$ & $-2.03 * * *$ \\
\hline$\theta^{\mathrm{PO}}$ & $2.365^{* * *}$ & $1.979 * * *$ & -21.80 & $1.7104 * * *$ & -5.02 & $1.712^{* * *}$ \\
\hline$\theta^{P 2}$ & $-59.726 * * *$ & $-7.217^{*}$ & 143.32 & $-1.2001 * * *$ & 1.02 & -3.529 \\
\hline$\theta^{\mathrm{Q} 0}$ & 8.00 & 6.070 & -3.062 & 3.990 & $1.8^{*}$ & 0.72 \\
\hline$\theta^{\mathrm{Q} 2}$ & -54.3 & -2.109 & 15.48 & 2.848 & $-16.55 * * *$ & -6.23 \\
\hline Log Liklihood & -82.311 & -84.076 & -85.450 & -93.676 & -92.99 & -84.202 \\
\hline AIC & 180.622 & 184.152 & 186.960 & 202.1527 & 201.991 & 184.00 \\
\hline $\mathrm{BIC}$ & 195.991 & 199.122 & 202.035 & 217.287 & 217.1263 & 199.382 \\
\hline $\begin{array}{l}\text { Ljung-Box } \\
\text { Q-Test (10) }\end{array}$ & $\begin{array}{l}\mathrm{h}=0 \\
\mathrm{pV} \text { alue }=0.852 \\
\text { stat }=5.544 \\
\text { cValue }=18.307\end{array}$ & $\begin{array}{l}\mathrm{h}=0 \\
\mathrm{pV} \text { alue }=0.683 \\
\text { stat }=7.441 \\
\text { cValue }=18.307\end{array}$ & $\begin{array}{l}\mathrm{h}=0 \\
\mathrm{pV} \text { alue }=0.689 \\
\text { stat }=7.381 \\
\text { cValue }=18.307\end{array}$ & $\begin{array}{l}\mathrm{h}=0 \\
\mathrm{pV} \text { alue }=0.434 \\
\text { stat }=10.0670 \\
\text { cValue }=18.307\end{array}$ & $\begin{array}{l}\mathrm{h}=0 \\
\mathrm{pV} \text { alue }=0.319 \\
\text { stat }=11.5020 \\
\text { cValue }=18.307\end{array}$ & $\begin{array}{l}\mathrm{h}=0 \\
\mathrm{pV} \text { alue }=0.405 \\
\text { stat }=10.413 \\
\mathrm{cV} \text { alue }=18.30 \\
7\end{array}$ \\
\hline
\end{tabular}

$*, * *, * * *$ indicate that value are statistically significant respectively at $10 \%, 5 \%, 1 \%$, 
Table 5- Mexico

\begin{tabular}{|c|c|c|c|c|c|c|}
\hline & STED/GDP & TED/GDP & STED/TED & STED/IR & IR/TED & IR/GDP \\
\hline$\sigma$ & 0.95 & 1.3 & 0.99 & 0.98 & 0.96 & 0.95 \\
\hline$\mu_{1}$ & $-0.37 * * *$ & $-0.28 * * *$ & $-0.28^{*}$ & $-0.33 * * *$ & $-0.27 * * *$ & $-035^{* * *}$ \\
\hline$\mu_{2}$ & $3.62 * * *$ & $2.86^{* * *}$ & $2.9 * * *$ & $1.95^{* * *}$ & $2.68^{* * *}$ & $3.61 * * *$ \\
\hline$\mu_{1+} \mu_{2}$ & $3.25 * * *$ & $2.58^{* * *}$ & $2.62 * *$ & $1.62 * * *$ & $2.41 * * *$ & $3.26 * * *$ \\
\hline$\emptyset_{1}$ & $0.77 * * *$ & $0.72 * * *$ & $0.73^{* * *}$ & $0.74 * * *$ & $0.73 * * *$ & $0.78^{* * *}$ \\
\hline$\emptyset_{2}$ & $-0.50 * * *$ & $-2.76 * * *$ & $-2.72 * * *$ & $-1.78 * * *$ & $-2.72 * * *$ & $-0.56 * * *$ \\
\hline$\phi_{1+} \phi_{2}$ & $0.27 * * *$ & $-2.04 * * *$ & $-1.99 * * *$ & $-1.04 * * *$ & $-1.99 * * *$ & $0.56 * * *$ \\
\hline$\theta^{\mathrm{PO}}$ & $2.37 * * *$ & $1.676^{* * *}$ & $7.938^{* * *}$ & $2.62 * * *$ & $0.868 * * *$ & $2.075^{*}$ \\
\hline$\theta^{\mathrm{P2}}$ & $-29.77^{*}$ & $-0.57 * * *$ & $-2.435^{* * *}$ & $-2.493 * * *$ & $1.940 * * *$ & -9.26 \\
\hline$\theta^{\mathrm{Q} 0}$ & 63.53 & 6.095 & 4.663 & $3.662 * * *$ & 4.92 & -2.744 \\
\hline$\theta^{\mathrm{Q} 2}$ & -46.11 & 0.310 & 1.067 & 3.247 & 1.612 & 44.31 \\
\hline Log Liklihood & -91.178 & -95.43 & -99.281 & -98.85 & -99.82 & -92.226 \\
\hline AIC & 198.356 & 206.860 & 214.562 & 213.715 & 215.653 & 200.452 \\
\hline $\mathrm{BIC}$ & 213.811 & 222.314 & 230.017 & 229.170 & 231.108 & 215.907 \\
\hline $\begin{array}{l}\text { Ljung-Box } \\
\text { Q-Test (10) }\end{array}$ & $\begin{array}{l}\mathrm{h}=0 \\
\mathrm{pV} \text { alue }=0.635 \\
\text { stat }=7.933 \\
\mathrm{cV} \text { alue }=18.307\end{array}$ & $\begin{array}{l}\mathrm{h}=0 \\
\mathrm{pV} \text { alue }=0.656 \\
\text { stat }=7.728 \\
\text { cValue }=18.307\end{array}$ & $\begin{array}{l}\mathrm{h}=0 \\
\mathrm{pV} \text { alue }=0.635 \\
\text { stat }=7.928 \\
\text { cValue }=18.307\end{array}$ & $\begin{array}{l}\mathrm{h}=0 \\
\mathrm{pV} \text { alue }=0.672 \\
\text { stat }=7.549 \\
\text { cValue }=18.307\end{array}$ & $\begin{array}{l}\mathrm{h}=0 \\
\mathrm{pV} \text { alue }=0.638 \\
\text { stat }=7.899 \\
\text { cValue }=18.307\end{array}$ & $\begin{array}{l}\mathrm{h}=0 \\
\mathrm{pV} \text { alue }=0.600 \\
\text { stat }=8.285 \\
\mathrm{cValue}=18.307\end{array}$ \\
\hline
\end{tabular}

$*, * *, * * *$ indicate that value are statistically significant respectively at $10 \%, 5 \%, 1 \%$, 